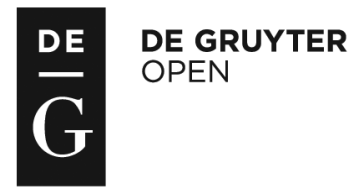

Administration, vol. 64, nos 3/4 (2016), pp. 61-89

doi: 10.1515/admin-2016-0025

\title{
The development of conflict resolution practices in Irish workplaces
}

\author{
William K. Roche \\ College of Business, University College Dublin
}

\begin{abstract}
This paper examines the development of procedures for conflict resolution in workplaces in Ireland and the more recent emergence of alternative dispute resolution (ADR) practices. Based on a synthesis of data from a series of studies and on a review of reports of conflict resolution innovations, the paper shows how conventional procedures for resolving collective disputes and individual employment grievances had become almost standard by the 1980s, while a series of ADR practices became features of conflict resolution from the 1990s. The changing character of conflict resolution procedures and practices is attributed to a series of influences that include the professionalisation of personnel and human resource management, the changing pattern and context of workplace conflict, the growing importance of multinational firms, and the emergence of professional training and expertise in the provision of ADR support services. The paper projects a continuing rise in the incidence and use of ADR practices but questions the extent to which organisations in Ireland are likely to adopt conflict management systems based on integrated sets of conflict resolution practices.
\end{abstract}

Keywords: Conflict resolution, alternative dispute resolution (ADR), workplaces, workplace conflict 


\section{Introduction}

In Ireland, as in other countries, recent years have witnessed a renewal of interest in workplace conflict and the practices employed by organisations to resolve conflict in workplaces (see especially Teague et al., 2015). While a number of studies have examined trends in workplace conflict and innovations in conflict resolution, especially under the rubric of alternative dispute resolution (ADR), no systematic review exists of how conflict resolution is handled in Irish workplaces, and of the influences that have shaped and reshaped the ways in which organisations have addressed workplace conflict. The purpose of this article is to provide such a systematic review for policymakers, the burgeoning number of conflict resolution professionals now active in the field, and scholars and students.

As the topic is broad, it is important to delimit the subject matter of the article. The focus is on workplaces, and developments in national agencies for conflict resolution will be considered only in so far as they impact on developments at workplace level. To provide the fullest possible picture, the article draws on all available historical, recent and current sources of quantitative and qualitative data, as well as on official reports. Wherever possible, data collected in representative national (probability) surveys of employers are used to establish the incidence of conflict resolution practices of different kinds.

The article is structured as follows. The first section examines the early development of procedures for conflict resolution in Irish workplaces, excavating the rather scattered and sometimes even obscure empirical literature on developments up to the 1990s. The next two sections review in detail the emergence and development of ADR practices. These are followed by a section that seeks to explain the long-term pattern of change identified in earlier sections. A concluding section summarises the main emerging themes and issues, and presents some tentative suggestions as to what the future may hold.

\section{The early development of conflict resolution in workplaces}

Data on historical developments in conflict resolution in workplaces in Ireland are scant. Nevertheless, the diffusion of formal dispute and grievance procedures appears to have developed hand in hand with the development of professional personnel and industrial relations management. To some degree, this reflected the growth in union density over the post-war period. Union density grew in a near 
progressive manner from the second half of the 1940s to a peak of 62 per cent in the early 1980s (judged in terms of unions' reported membership levels). Higher levels of union organisation and an expansion in the reach of unions across sectors of the economy would have given added impetus to the formalisation of procedures for conflict resolution in workplaces. The same was true for the formalisation of union recognition and collective bargaining arrangements in the public service. Other related developments were also significant. These included a vogue from the 1960s in the negotiation of so-called 'comprehensive agreements' by employers and unions, which covered pay and conditions and also disputes procedures (Roche, 1992, p. 313). Also important from the 1970s was the growing body of employment legislation, especially the Unfair Dismissals Act, 1977. The predecessor of IBEC, the Federated Union of Employers, also observed in 1980 that conflict resolution procedures developed in part due to a widening substantive agenda in industrial relations, linked to accelerating change in product markets, labour markets and technology (Federated Union of Employers, 1980).

Despite these developments, or without referring to empirical evidence, the Commission of Inquiry on Industrial Relations, established in 1978, complained about the absence of widely applicable dispute procedures. The commission viewed this as a 'fundamental defect of current industrial relations practice' (Commission of Inquiry on Industrial Relations, 1981, p. 87). However, studies during the 1970s and 1980s indicated that disputes and grievance procedures were quite widely prevalent in Irish industry. A 1975 survey of manufacturing firms by Gorman et al. found that upwards of 80 per cent of large firms (with 500 or more employees) and more than 66 per cent of medium-sized firms (100-499 employees) had formal procedures in place for dealing with claims, grievances and disciplinary action. The Commission of Inquiry's claim had greater validity in the case of smaller employers. Less than a third of small firms (25-99 employees) were found to have had formal procedures in these areas. This finding accords with a later study of small firms in the mid-west which found that few, irrespective of whether they were unionised or non-union, had formal procedures for conflict resolution (Gunnigle \& Brady, 1984). This was the case even though a significant number had been involved with cases at the Rights Commissioners, the state agency that dealt with mainly individual grievances and alleged violations of employment rights, and at the Employment 
Appeals Tribunal (EAT), which dealt mainly with allegations of unfair dismissals.

A 1984 survey of 141 manufacturing firms with 50 or more employees found that nearly 90 per cent of companies had formal procedures. The incidence of procedures in unionised firms was highest (Murray, 1984). The position outside manufacturing was unclear; some observers claimed that formal procedures were significantly less prevalent in services (Wallace, 1987, p. 134). A representative survey of workplaces in firms with 20 or more employees in 1996-7 collected data on grievance and dispute resolution, revealing that 40 per cent of workplaces in Irish-owned firms made use of state-provided third-party facilities for resolving disputes, compared with 70 per cent of workplaces in multinational subsidiaries. Also, 20 per cent of Irish workplaces confined grievance handling within the firm, compared to a third of foreign multinationals (Geary \& Roche, 2000, pp. 117-8). The incidence of formal procedures was again found to be substantially lower in workplaces in smaller firms. Multinationals, including US multinationals, were more likely than their Irish counterparts to resort to state agencies to resolve disputes, or to operate forms of grievance handling where the formal final stage of procedure was confined within the firm.

Data collected from a representative sample of private and public sector employers in 2009 showed that formally agreed dispute resolution procedures were almost universal in the public sector, where 97 per cent of employers implemented such procedures. Almost 70 per cent of private sector employers also implemented formal dispute procedures, an increase on the 52 per cent who had implemented formal dispute procedures in 2003 (Watson et al., 2009, p. 17). Comparable data for 2003 allow for a profile of variations in the incidence of formal dispute resolution procedures across private sector firms. Sectoral variations were not found to be significant when allowance was made for other influences: with larger employers, multinational employers and unionised employers were significantly more likely to operate formal dispute procedures (Williams et al., 2003, pp. 59-63). These results suggest that earlier variations that may have existed in the incidence of conflict resolution practices across different industries - over and above associated industry variations in the size of firms and the occurrence of union recognition - may have disappeared by the early 1990s.

The most detailed data on the incidence of procedures and practices for resolving conflict, especially ADR procedures and 
practices, derive from a survey conducted in 2008 by Hann et al. (2009). A large representative sample of 505 firms in Irish private and commercial state-owned sectors employing 20 or more people revealed that 62 per cent, employing some 79 per cent of the workforce within the sectors covered by the survey, operated formal written grievance and disciplinary procedures that involved progressively higher levels of management in resolving disputes affecting individual employees (Hann et al., 2009, p. 17). As in earlier surveys, these multistep procedures were found to be significantly more pronounced in medium and large firms (employing 50 or more people) than in small firms, and were somewhat more pronounced in manufacturing firms than in service firms. Formal written disputes procedures for resolving conflict involving groups of employees were in place in 43 per cent of workplaces, employing about 55 per cent of the workforce in the sectors covered by the survey. These procedures were again more common in medium and large firms than in small firms ( 70 per cent compared to 41 per cent). Formal procedures for resolving individual conflict were more common in unionised workplaces than in non-union workplaces (67 per cent compared to 61 per cent), and so also were formal procedures for handling group conflict (51 per cent compared to 40 per cent) (Hann et al., 2009, ch. 4). The results of earlier research showing that formal grievance and dispute procedures were more common in foreign-owned multinationals than in Irish firms were mirrored in this study. Among general influences on firms' approaches to conflict resolution, those that emerged as priorities were: responding to the expanding body of employment legislation, expediting conflict resolution and resolving conflict within the boundaries of organisations' priorities (Hann et al., 2009, pp. 14-16).

\section{The emergence of alternative dispute resolution practices}

While formal written procedures for resolving individual and collective conflict had become widespread in large firms by the 1990s, a growing number of firms also began to adopt so-called 'alternative dispute resolution practices' for resolving both forms of workplace conflict. ADR practices differ from conventional approaches to conflict resolution in various ways. Individual ADR practices seek to promote 'informal' approaches to grievance resolution through the involvement of external or internal mediators or facilitators, through making provision for a company or 'organisational ombudsman', 
through employee 'hotline' or email-based 'speak-up' services, or through grievance adjudication panels comprising employees' peers and/or managers. Collective ADR practices similarly depart from conventional dispute resolution procedures by, for example, engaging independent experts as facilitators to prevent deadlock occurring between employers and unions; by promoting consensus-generating methods of gaining agreement, such as 'brain storming' and problem solving; and by replacing conventional adversarial collective bargaining with 'interest-based' or 'win-win' bargaining. In line with the latter approach, employers and unions seek to generate multiple options for dispute resolution and to avoid using power or coercion.

Table 1: ADR practices for handling individual grievances in firms in Ireland

\% of firms \% of employees

Conventional practices

Formal written grievance \& disciplinary

procedures involving progressively higher

levels of management in resolving disputes

78.5

ADR practices

Use of external experts (other than Rights

Commissioners, LRC or Labour Court)

Use of review panels comprising

employees' peers

Use of review panels comprising managers

Use of an employee 'hotline' or

email-based 'speak-up' service

Use of company ombudsperson

1.6

Source: Based on a representative sample of 505 firms in the private \& commercial state-owned sectors in Ireland, employing 20 or more employees, in 2008. For details of the survey, see Hann et al. (2009).

\section{The incidence of ADR practices for resolving individual and group conflict}

The overall incidence and workforce penetration of individual and group ADR practices by 2008 are outlined in Tables 1 and 2 . Individual forms of ADR, other than the use of external experts acting in a mediation, facilitation or other related capacity, remained 
Table 2: ADR practices for handling group disputes in firms in Ireland

\% of firms \% of employees

Conventional practices

Formal written grievance \& disciplinary

procedures involving progressively higher

levels of management in resolving disputes

50.8

71.2

Resort at final stage in procedure, where

deadlock remains, to LRC and Labour

Court

40.6

ADR practices

Use of external experts to assist in

reaching settlement or to prevent

deadlock in discussion or negotiation

with the company

30.9

42.5

Use of 'brainstorming', problem-solving

and related techniques to solve problems

or resolve disputes

29.8

26.2

Use of formal interest-based ('win-win')

bargaining techniques to resolve disputes

17.2

28.3

Source: Based on a representative sample of 505 firms in the private \& commercial state-owned sectors in Ireland, employing 20 or more employees, in 2008. For details of the survey, see Hann et al. (2009).

uncommon. The incidence and penetration of various forms of group ADR were, however, significantly higher. Large minorities of firms reported having adopted, or resorting to, one or more forms of group ADR, including assisted negotiations, brainstorming or related problem-solving techniques and interest-based bargaining. These forms of ADR were found to have covered significant sections of the workforce.

Further analysis of the data reported in Tables 1 and 2 sought to establish whether either individual or group practices for handling conflict, or both sets of practices in combination, were adopted in systematic sets or bundles. The literature on so-called 'conflict management systems' (CMSs) views such combinations or bundles of individual and/or group ADR practices as the most sophisticated and potentially most effective ways of resolving workplace conflict (Roche \& Teague, 2012a). 


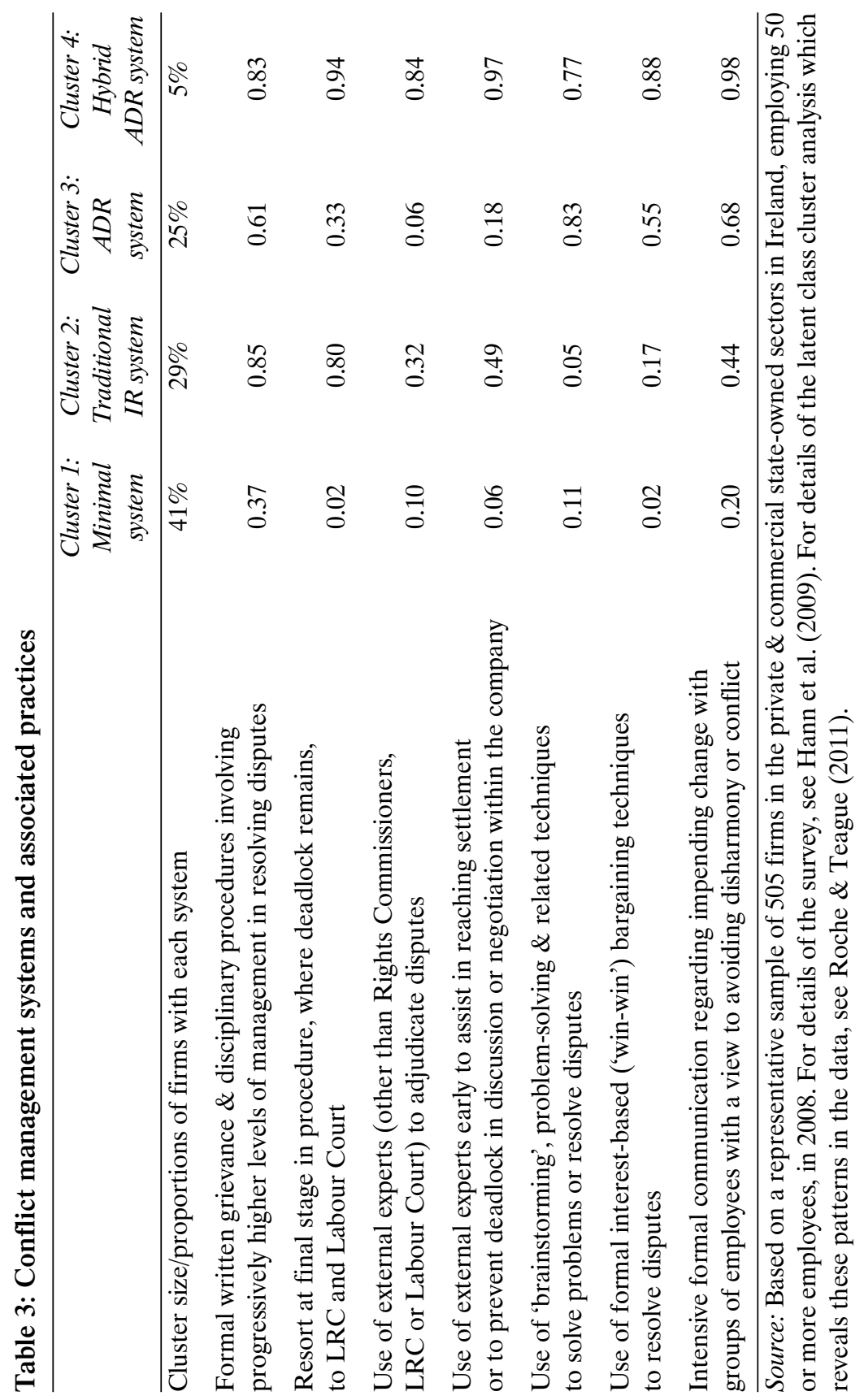


In the case of individual practices, statistical analysis could identify no systematic sets or bundles. This finding suggested a pattern in which firms had adopted many permutations and combinations of practices, and pointed to a piecemeal rather than systemic pattern of adoption of individual forms of ADR. 1 This does not mean that no such systematic CMSs existed. But it does suggest that the incidence of CMSs was very limited with respect to the handling of individual grievances.

In the case of group forms of ADR the picture was different (see Roche \& Teague, 2011). Table 3 presents the results of statistical analysis of the pattern of adoption of practices for handling group conflict. It emerges that firms had adopted these practices in a more systematic manner. A model identifying the four sets of practices, or four CMSs reported in Table 3, provides a good statistical representation of the pattern of adoption of group practices. ${ }^{2}$ Four groups of firms with quite distinct sets of practices or CMSs were evident. The figures in the columns of Table 3 provide an estimate of the probability that firms in each group have adopted the practices outlined in the rows of the table. What can be described as a 'minimal system' prevailed in about four out of ten firms and involved few group conflict management practices other than (sometimes) the use of formal multistep disputes procedures. About 30 per cent of firms had adopted what was termed a 'traditional industrial relations system'. This comprised formal disputes procedures, resorting to the Labour Relations Commission (LRC) and the Labour Court and also, in about one in two cases, using facilitated negotiations. The LRC handled both individual employment grievances, through the Rights Commissioner Service and mediation service, and also collective disputes, through its conciliation service. The Labour Court acted as an adjudication agency in respect of both individual and collective employment grievances and disputes. ${ }^{3}$

1 The statistical modelling method used is latent class cluster analysis. For details, see Roche \& Teague (2011).

${ }^{2}$ Because the response rate among smaller firms was significantly lower than for larger firms, the analysis was confined to firms with fifty or more employees.

${ }^{3}$ In 2015 the LRC, the Labour Court, the EAT, the Equality Authority and the National Employment Rights Authority (responsible for policing and enforcing employment standards) were reconfigured into two agencies: the Workplace Relations Commission (WRC), which is responsible for dealing in the first instance with all individual and collective grievances and disputes, and for protecting and enforcing employment standards; and the Labour Court, which is now an appellate adjudication body for individual employment grievances and collective disputes. 
Around 25 per cent of firms relied to significant, if varying, degrees on ADR practices combined with formal disputes procedures. Finally, a small grouping of about 5 per cent of firms reported using all conventional and ADR practices listed in combination, and this group was labelled as having adopted a 'hybrid ADR system'.

\section{Influences on the adoption of individual and group ADR practices}

As well as identifying levels and patterns of adoption of individual and group practices for handling conflict, the 2008 survey also permitted an analysis of influences on the uptake of ADR practices. Because firms had adopted practices for handling individual conflict in many permutations and combinations, the appropriate way to proceed was to examine influences on each discrete practice (see Roche \& Teague, $2012 b)$. Union avoidance was not found to be associated with the adoption of the individual ADR practices reported in Table 3. Nor did the incidence of ADR practices vary on the whole depending on whether firms recognised unions or not - the exceptions being resorting to external experts in grievance handling and, more surprisingly, to review panels comprising managers, which were more pronounced in unionised firms. Firm size was of little significance, as was whether businesses were engaged in manufacturing or services. US multinationals were significantly more likely than Irish firms to have used hotline or related practices and organisational ombudsmen, and were less likely to have used external experts. These features of US firms pointed to a preference for confining conflict management within the boundaries of organisations or for operating private systems of organisational justice' (Roche \& Teague, 2012b). The most significant influence on the adoption of a range of individual ADR practices was the degree to which firms had implemented a broader set of human resource management (HRM) practices. These practices were also associated with the incidence of conventional multistep individual grievance procedures. The set of HRM practices associated with the adoption of ADR practices comprised a formal performance management system; individual performance-related pay; group performance-related pay; profit sharing/share ownership; formally designated team-working; regular employee surveys; the assessment of employees' values; attitudes or personality at the time of hiring; a policy of no compulsory redundancies; common (single-status) terms and conditions of employment; a system of regular team briefings that provides employees with business information; and internal career progression as a formal objective for all employees. The strong but by 
no means wholly consistent pattern of association between HRM, thus understood, and ADR practices suggested that ADR was commonly aligned with HRM in firms. This alignment suggests that just as firms committed to HRM seek to promote common or unitary objectives between the employer and their employees, ADR seeks to emphasise so-called 'interest-based' and problem-solving methods, rather than 'rights-based' ways of resolving conflict (Roche \& Teague, 2012b).

In examining influences on the adoption of practices for handling conflict involving groups of employees, account can be taken of the finding that group practices had been adopted more systematically or in bundles. As such, the focus should be on influences on the adoption of the different CMSs outlined above, and the objective becomes identifying influences on why firms have adopted any of these systems as compared to the other systems identified. ${ }^{4}$ The ADR system, compared to the traditional industrial relations systems, was much more likely to have been adopted in non-union companies. Firms with hybrid ADR systems had much the same profile with respect to unionisation as firms with the traditional industrial relations system. Compared to the ADR system, the hybrid ADR system was also many times more likely to have been adopted by Irish-owned firms. Consistent with the results reported above, the adoption of the ADR and hybrid ADR systems was also associated with firms' commitment to HRM practices (Roche \& Teague, 2011). The analysis ruled out a range of other possible influences on firms' decisions, such as sector, the features of competitive strategies, the proportion of the workforce engaged in knowledge-intensive work and the period when operations commenced in Ireland (see Roche \& Teague, 2011).

Another source of survey data on conflict resolution in workplaces derives from Doherty \& Teague's survey of eighty-three non-union multinational firms (Doherty \& Teague, 2012). Table 4 reports the results. Comparing these results with those from the 2008 survey of all firms, we find that the incidence of conflict management practices that are comparable across the two surveys was much higher in multinationals than in the general population of firms. The practices in the non-union multinationals all appeared to focus on the resolution of conflict involving individual employees. Doherty \& Teague (2012) emphasised that only a minority of the firms surveyed (about 25 per cent) used a wide variety of conflict management

4 The method of statistical analysis used was multinomial regression. For details, see Roche \& Teague (2011). 
Table 4: Conflict management practices in non-union multinationals in Ireland

\begin{tabular}{lc}
\hline Conflict management practice & \% firms \\
\hline Formal grievance procedure & 100.0 \\
Mediation & 39.5 \\
Facilitation & 43.2 \\
Arbitration & 18.5 \\
Employee hotline & 25.9 \\
Open door policy & 97.5 \\
Management review & 65.4 \\
Peer review & 16.0 \\
Ombudsperson & 6.2
\end{tabular}

Source: Data reported in Doherty \& Teague (2012).

Note: Sample size $=83$.

practices, implying that CMSs were again not widely prevalent in multinationals. One of the principal reasons given for this was that managers at the subsidiary level in multinationals avoided fostering innovation in this area of HR for fear of drawing attention to problems or concerns about conflict in the workplace (Doherty \& Teague, 2012). Reflecting the pattern of influences on the uptake of ADR practices in the general population of firms, the important influences identified on conflict resolution in multinationals involved complying with employment legislation and resolving conflict in-house. Also identifed was a concern to enhance employee morale and motivation (Doherty \& Teague, 2012, p. 66).

\section{Line and supervisory managers and ADR}

Commonly included under the banner of ADR practices are the training and involvement of line and supervisory managers in troubleshooting and conflict resolution, and these managers being held accountable for their performance in resolving conflict. In nonunion multinationals, however, the monitoring and evaluation of line management performance with respect to conflict resolution is uncommon (Doherty \& Teague, 2012, p. 67).

The role of line managers in conflict resolution in firms in general can be examined using data from the 2008 survey of firms with twenty or more employees (Hann et al., 2009). Table 5 reports the views of managers most familiar with conflict handling on various aspects of line and supervisory management involvement in conflict resolution. 


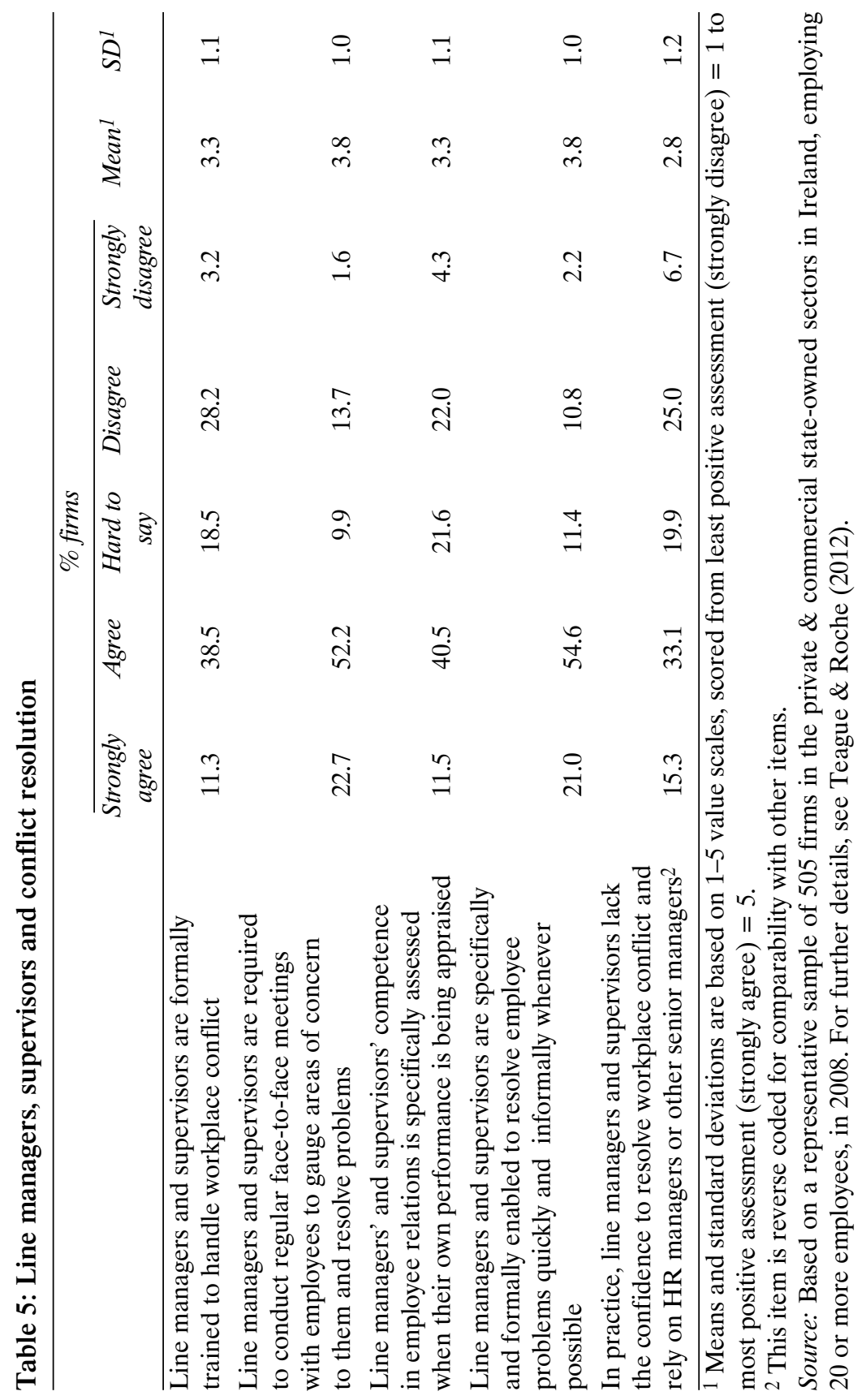


In most firms, line managers and supervisors were seen to be routinely engaged in the resolution of conflict in the workplace. They were also required in the main to conduct regular face-to-face meetings with employees to gauge areas of concern and to resolve problems. The majority of firms expected line managers to play an important role in terms of continually gauging the mood of employees and solving any identified problems. A total of 76 per cent of firms either strongly agreed or agreed ( 21 per cent and 55 per cent, respectively) with the statement that their organisations formally enabled line managers to resolve employees' problems quickly and informally, wherever possible.

It is evident that the majority of firms had assigned line managers and supervisors a role in preventing and solving workplace conflict. But what of support and incentive arrangements to encourage line managers and supervisors to perform this role? Just under half of firms agreed that line managers and supervisors were formally trained to handle workplace conflict. In addition, just over half agreed that line managers' and supervisors' competence in employee relations was specifically assessed when their performance was being appraised. These results strongly suggest that line managers and supervisors were often involved in conflict resolution without formal organisational or management supports, such as training, or without being held accountable through performance management.

Just under half of the firms in the survey agreed with the statement that line managers and supervisors lacked the confidence to resolve workplace conflict, and relied instead on HR managers or other senior managers for this purpose. Only 7 per cent strongly disagreed that line managers lacked the confidence to resolve workplace conflict, and one in four respondents disagreed with the statement. This suggests that only about a third of the surveyed firms had a positive opinion about the confidence of line managers and supervisors to handle workplace conflict. This gained the lowest level of endorsement by firms in the survey. Overall, the findings suggest that a sizable number of firms were characterised by a major asymmetry or imbalance with respect to the activities of line managers and supervisors in managing conflict. Conflict management responsibilities are often delegated to line managers. However, inadequate support structures were put in place to help them perform this role and they often had little capacity to handle conflict management confidently, without relying heavily on other executives. 
Studies by Teague \& Roche (2012) and Roche \& Teague (2012b), based on the same survey, examined whether proactive line and supervisory management engagement in conflict management affected a range of organisational outcomes. They also examined whether the prevalence of individual and collective ADR practices and configurations of conflict management practices resembling the properties of CMSs affected organisational outcomes. For these purposes, firms were asked to assess their performance across a series of areas relative to other companies in their industry. The areas covered were the level of labour productivity, the rate of voluntary labour turnover, the rate of absence through sickness or other causes, and the capacity to handle change. Responses were scored on a scale, ranging from 1 ('a lot below average') to 5 ('a lot above average'). They were also asked to respond to the following statement: 'conflict resolution practices [in use] contribute positively to the climate of employment relations in the company'. The four response categories provided varied from 'strongly disagree' to 'strongly agree'. A scale measuring greater or lesser degrees of line and supervisory management engagement with conflict resolution was created by summing the various facets of line and supervisory managers' involvement in workplace conflict, outlined in Table 5.

The analysis revealed that line and supervisory engagement in conflict resolution was positively associated with firms' relative labour productivity and their capacity to handle change. Line and supervisory engagement was also associated with a positive employment relations climate and with a lower level of absenteeism due to illness or other causes (Teague \& Roche, 2012). The incidence of individual or collective ADR practices, on the other hand, was found to have no significant association with the outcomes examined.

The presence of HRM practices and a proactive approach to managing conflict were found to be direct antecedents of line and supervisory engagement in conflict resolution. Competitive postures emphasising innovation or quality and knowledge-intensive work activity were found to be indirect antecedents through their influence on the adoption by firms of HRM practices (Teague \& Roche, 2012).

There appears, thus far, to be few examples of formal, purposedesigned CMSs in firms in Ireland - even among multinationals, where these might be expected to have a reasonable prevalence. Roche \& Teague (2012b) sought evidence from the 2008 survey of the kinds of systems effects associated with CMS theory in the international literature. One of the key postulates of CMS theory is 
that rights-based practices (e.g. adjudication within or outside the firm) and interest-based practices (e.g. mediation or assisted bargaining) in combination - and according to some versions of the theory in critical mass - should have significant positive effects on a range of organisational outcomes. Focusing on the outcomes discussed above, no evidence consistent with the theory could be found in firms (see Roche \& Teague, 2012b). This finding needs to be understood in the light of the fact that in Ireland conflict management practices are seldom, it seems, proactively configured in accordance with the formal design principles set out in the CMS literature.

Data on the prevalence of specific procedures for managing bullying and harassment were collected in a 2006/7 survey of private and public sector employers. Half of all organisations reported having a formal policy on bullying and harassment, the incidence rising to eight out of ten organisations in the public sector (O'Connell et al., 2007, p. 79). Awareness of codes of practice (issued by national agencies) dealing with bullying and harassment was associated with the incidence of such policies, as was organisational size. Thirty per cent of organisations reported having informal procedures for dealing with bullying, while 50 per cent had formal policies and 35 per cent used independent complaints procedures - these options not being mutually exclusive (O'Connell et al., 2007, p. 79). Thus, it appears that both legislation on bullying and harassment at work and codes of practice influenced the diffusion of formal policies and procedures across organisations, especially in the case of organisations in the public sector.

\section{Other innovations in workplace conflict resolution}

The picture that emerges through the statistical analysis of survey data can be supplemented by reports in the specialist industrial relations media and other sources of innovations in conflict resolution and ADR within firms and workplaces. These will be categorised and discussed on the basis of the types of innovations involved.

\section{Dispute resolution committees}

Historically some large Irish unionised firms - such as the state-owned electricity utility, the ESB, or the state broadcaster, RTÉ - established domestic committees or tribunals to resolve disputes. The ESB's Joint Industrial Council originated in two statutory tribunals, one for whitecollar workers and the other for manual workers, established to handle 
grievances and disputes involving the company's pension schemes. Over time these developed into fully fledged bodies for adjudicating claims and grievances, and they were eventually merged into a single adjudication body. The RTÉ in-house Industrial Relations Tribunal was established in the mid 1990s in succession to a temporary 'special adjudication committee' formed in the wake of a serious strike in 1992. The tribunal issues binding decisions in respect of technology and work practices, and non-binding decisions on other matters.

There have been a number of recent developments involving the creation of in-house dispute resolution bodies with various functions and powers. The environmental waste firm Oxigen agreed an in-house disputes resolution panel with SIPTU in 2006 as part of a new dualchannel disputes procedure. As part of an agreement with its unions on cost-saving and related measures after a sharp downturn in business in 2009, the Dublin Airport Authority (DAA) instituted an internal disputes committee, with an independent chair, to adjudicate in a non-binding manner on disputes arising during the implementation phase of the agreement. A subsequent agreement on the start-up of the DAA's new Terminal 2 at Dublin Airport made provision for binding determinations by the committee. 5 The establishment of the internal disputes committee was a long-held management objective and reflected a concern to expedite dispute resolution and to counter 'narcotic' and 'chilling' effects that had left the company overly reliant on the LRC and the Labour Court (Roche et al., 2013, pp. 159-60).

Changes to conflict resolution procedures in Veolia Transport (which subseqently merged into Veolia Transdev and then became Transdev), the multinational firm that operates the Dublin City tram service (Luas), have also involved the creation of an in-house dispute resolution tribunal. At Veolia a new disputes procedure involving the in-house tribunal replaced an existing 'no strike agreement'. The new procedure set down a standard series of steps that include the referral of disputes to the LRC/WRC if the parties have been unable to resolve these through direct negotiations within the firm. If unresolved following resort to the LRC/WRC, disputes are referred to the Veolia (later Transdev) Transport In-House Dispute Resolution Tribunal. This body has an independent chair and one nominee each from the company and union. The finding of the tribunal is intended to be authoritative but is binding only if the parties agree in advance. If a tribunal decision is rejected following a union ballot, the dispute is

5 Industrial Relations News (IRN), available at www.irn.ie, 24 November 2010. 
referred to the Labour Court. If the Labour Court's recommendation is rejected, the union again ballots on industrial action. A further feature of the agreement is that it provides for adjudication on complaints from either of the parties that the procedure is not being adhered to by the other party. ${ }^{6}$ The procedure was subsequently modified during the course of a dispute involving LUAS drivers when a facilitator brokered talks between management and the union prior to a Labour Court hearing. ${ }^{7}$ The new procedure failed to prevent a series of work stoppages in 2016 over a union claim for significant pay increases. ${ }^{8}$

A new dispute resolution procedure at the Central Bank is similar both in terms of the stages set down and in making provision for 'procedural adjudication'. ${ }^{9}$ In both these cases a new procedural stage, involving a new body (the in-house tribunal), was created with a view to maximising the scope for resolving disputes and avoiding industrial action. Procedural adjudication was also provided and the new procedures in both organisations sought to give expression to a shared ethos of seeking evidence-based solutions to disputes and promoting 'problem-solving'. In a further development at the Central Bank, an overhaul of the performance management system made provision for an independent appeals process, the outcome of which is binding. ${ }^{10}$

Following a series of disputes resulting in serious disruptions to its business, Aer Lingus and its unions also entered talks on establishing an internal tribunal to facilitate the speedier and more definitive resolution of disputes at the airline. 11 The new procedure allows for the referral of disputes to the WRC and Labour Court, but only after these have been heard by the internal tribunal. A new dispute resolution board has also been created at the Irish Aviation Authority. ${ }^{12}$ In this instance the decisions of the board are binding on the employer and the union. ${ }^{13}$

\footnotetext{
${ }^{6}$ IRN, 24 March 2010.

${ }^{7}$ IRN, 5 September 2012.

8 IRN, 18 February 2016.

${ }^{9}$ IRN, 21 March 2012.

10 IRN, 20 February 2013.

11 IRN, 17 July 2014.

12 IRN, 22 July 2015.

13 IRN, 14 April 2016.
} 


\section{No-strike arrangements}

Some revisions to disputes procedures, such as that at the Irish Aviation Authority, have involved the introduction of binding arbitration or adjudication as the final stage of procedure. While such a step could be tantamount to the inclusion of no-strike clauses in collective agreements, in practice the scope of binding arbitration or adjudication tends often to be circumscribed in various ways. The disputes procedure in Oxigen sets down two alternative channels for resolving disputes. The first of these is a standard multistep procedure, culminating in referral to the LRC and Labour Court. The second makes provision for the involvement of a two-person team of joint facilitators' who act in a mediating capacity. Where mediation fails, there is provision for onward referral to the in-house disputes resolution panel for binding arbitration. The panel comprises the joint facilitators and an independent chair. This arrangement resembles 'med-arb', where mediators play a role in arbitration. This procedural channel was used to resolve a dispute over the crewing of new trucks. ${ }^{14}$ A further instance of the circumscribed use of binding arbitration as a final stage in procedure arises in a cost-saving agreement in ESB. Under the agreement, disputes over how shortfalls from agreed costsaving targets are to be achieved are referred to binding arbitration by the ESB's Joint Industrial Council. ${ }^{15}$ A more all-encompassing case of a no-strike arrangement arising under the start-up agreement for Terminal 2 at Dublin Airport provided for binding arbitration by the firm's internal disputes body on matters covered by the agreement. ${ }^{16}$

\section{Work continuity clauses}

Whether formally or informally, collective agreements in Ireland historically have often incorporated status quo clauses or conventions whereby any disputed terms and conditions or work practices continue to pertain pending the resolution of such disputed arrangements through agreed procedure (Von Prondzynski \& Richards, 1994, p. 165). What seems like the reverse of this principle has become a feature of revised disputes procedures in some firms. In these cases, pending the resolution of a disputed work practice or management direction, employees are expected to accept a manager's instruction, possibly under protest. This principle is contained in a disputes

14 IRN, 14 June 2006, 20 September 2006.

15 IRN, 16 January, 20 February 2013.

16 IRN, 24 November 2010. 
procedure agreed between the Dublin Port Tunnel operator, Transroute Tunnel Operations, and SIPTU. ${ }^{17}$ The same principle is found in a new disputes procedure agreed between Aer Lingus and SIPTU. The Aer Lingus-SIPTU agreement states that if a dispute arises regarding any matter covered by this agreement, in order to preserve the smooth running of the operation the employee will unreservedly work as instructed by their supervisor/manager pending a resolution of the dispute'. ${ }^{18}$ A reference in the same procedure that unresolved disputes should be referred to the Labour Court for 'decision and enforcement' led to disagreement between the parties as to whether Labour Court recommendations would henceforth be binding, which would in effect introduce a 'no-strike' provision into the procedure - an interpretation disputed by the union. ${ }^{19} \mathrm{~A}$ restructuring agreement concluded between the insurance firm FDB and its unions also contained a clause in the grievance and disputes procedure which stated that in the event of a dispute arising on the implementation and interpretation of the agreement, employees agree to work in accordance with management instruction, under protest if necessary, while the point at issue is processed through normal procedure'. ${ }^{20}$

\section{Organisational ombudsman services}

To date, few organisational ombudsmen services have been reported in organisations in Ireland, and some that have been reported seem to resemble investigation functions more than the advisory and facilitative services typically provided by organisational ombudsmen. GE Healthcare and University College Cork (UCC) provide instances where staff ombuds functions of different types are in place. The staff ombuds service in UCC was introduced in the wake of several highprofile conflicts and is designed to operate like a classical organisational ombudsman service, providing advice and guidance to parties involved in work-related grievances but with no powers of investigation or compulsion. The new conflict resolution procedure introduced in Aer Lingus also provides for the appointment of a 'case ombudsman' to resolve individual employment grievances, reportedly through mediation or adjudication. ${ }^{21}$

\footnotetext{
17 IRN, 12 March 2008.

18 IRN, 16 June 2010.

19 IRN, 16 June 2010.

20 IRN, 13 April 2011.

${ }^{21}$ IRN, 9 June 2016.
} 


\section{Mediation and facilitation}

The number of people trained in mediation and offering mediation services has grown dramatically in Ireland (see Teague et al., 2015). The LRC and Equality Tribunal also provided mediation services and these have been carried through into the WRC. However, the incidence of mediation conducted by the new WRC remains very modest in comparison with the incidence of adjudication or collective conciliation..$^{22}$

A number of unionised organisations have introduced mediation into procedures for grievance handling. The grievance procedure in the telecommunications firm eir (formerly eircom), which was originally agreed in the then state-owned company Telecom Éireann, contains a final stage that involves referral to what is known as a 'mediation committee'. The committee has an independent chair and up to three members, drawn from management and unions. The committee issues a report and a recommendation. Mediation, thus understood, seems very much like adjudication, with the panel operating more along the lines of a peer-review body than through mediation in the more widely understood sense (Teague et al., 2015, ch. 5).

Mediation in the more usual sense is provided in the Central Bank under a further development in the conflict resolution procedure. Trained internal volunteers act as mediators within a procedure that seeks to resolve workplace grievances informally as close to the source as possible, without resorting to more formal processes. The issues that can be referred to mediation appear unrestricted. ${ }^{23}$ In the case of the Oxigen disputes procedure, one of the two agreed channels involves mediation by joint facilitators, prior to arbitration. In 2009 the Health Service Executive (HSE) introduced a national mediation policy and procedure within the health and social care services. The new procedure followed a review of policy on dignity and respect at work. Trained internal mediators provide the service within the remit of the HSE dignity at work policy. Other workplace problems can also be mediated (Health Service Executive, 2009a). Mediation can be attempted at any or all stages of the procedure subsequent to attempts by local managers to resolve grievances directly. A 'loop back' facility is also provided for allowing the parties to enter mediation during formal investigation, or subsequent to this. An annual mediation

22 IRN, 16 June 2016.

23 IRN, 5 December 2012. 
report for 2009 recorded sixty-six cases for the six months of the year during which mediation was in operation. Most of the cases related to allegations of workplace bullying (Health Service Executive, 2009b). No further reports have been published. In a case involving a worker disputing being moved from one position to another in the medical device manufacturer Covidien, the Labour Court recommended that mediation be used to facilitate the worker returning to their previous position. ${ }^{24}$ A new service was established by a group of independent professionals aimed at providing a range of mediation and investigation services in circumstances where incidents of conflict involved senior executives. 25 The Pensions Ombudsman also advocated the use of mediation in grievances arising from disputes regarding pension entitlements. ${ }^{26}$

The establishment of mediation programmes supported by internal or external mediators has escalated in recent years. Other than the cases outlined above, mediation programmes have been established across a wide range of firms and organisations, including Aramark, Irish Rail, An Post, ESB, Dublin Port, Bus Éireann, Dublin Bus, Teagasc, The Courts Service and a number of local authorities.

In the areas of industrial relations and collective bargaining, a 'mediator' was appointed by the Minister for Arts, Heritage and the Gaeltacht to work with employers and unions to address perceptions of an uncompetitive industrial relations environment in the Irish film industry. ${ }^{27} \mathrm{~A}$ mediator also became involved in a dispute between Hewlett-Packard and the Irish Bank Officials Association and, acting, it appeared, in a quasi-adjudicative capacity, put forward proposals on the resolution of the issues in dispute between the parties. ${ }^{28}$

Facilitators engaged by organisations (in agreement with their unions) have become an established feature of collective conflict resolution in Irish industrial relations during the past couple of decades. Facilitators have sometimes been provided by the LRC/WRC and by the Labour Court. Facilitators are also sometimes enaged privately by employers and unions. Facilitators are most commonly engaged to support collective bargaining in circumstances involving complex, multistranded change and restructuring programmes.

\footnotetext{
24 IRN, 15 May 2013.

25 IRN, 12 March 2013.

${ }^{26}$ IRN, 5 June 2013.

27 IRN, 5 June 2013.

${ }^{28}$ IRN, 16 January 2013.
} 
Examples are provided by the engagement of private facilitators in Ulster Bank, the Central Bank, Dublin City Council and Boliden Tara Mines.

While the Labour Court more frequently refers complex cases back to the LRC/WRC for further deliberation, the court occasionally mandates private facilitation or co-facilitation by professionals with a union and an employer background. This occurs in instances where the court forms the view that the parties to disputes could benefit from further direct engagement. Examples of facilitation and co-facilitation mandated by the Labour Court are provided by a dispute over pay at Liebherr Container Cranes, a dispute over security services at the Central Bank and a dispute over staffing levels at Monaghan General Hospital. Instances have also arisen, as in the case of the 2014 dispute over temporary pay cuts at Irish Rail, where employers have engaged a private facilitator subsequent to the rejection of Labour Court recommendations to explore whether a basis for settlement might still be found (Teague et al., 2015, ch. 11).

\section{Mediation-arbitration ('med-arb')}

There are few reported instances of mediation linked with arbitration, or 'med-arb', as this process is understood in the international literature. In this form of collective ADR, an adjudicator or mediator is permitted to seek a mediated settlement between the parties to a dispute before acting as arbitrator or adjudicator proper. The dispute resolution procedure agreed between Ulster Bank and the Irish Bank Officials Association appears to make provision for such a role. The dispute resolution committee at the Central Bank also adopted an informal version of this procedure during a dispute in 2013-14, when the committee's chair and members facilitated agreement on a number of issues between management and unions before the remaining issues in dispute were subject to adjudication by the same parties.

\section{Explaining the development of conflict resolution in workplaces}

Having reviewed the development of procedures and practices for conflict resolution in Irish workplaces, this section highlights the main influences on the patterns identified. These influences are interdependent. First, conflict resolution in workplaces evolved in line with the professionalisation of personnel (including industrial relations) and HRM. This significant influence on the early develop- 
ment of conflict resolution procedures was also subsequently an important influence on the uptake of ADR practices, which, as research on Ireland has shown, were often associated with the adoption by firms of wider sets of HRM practices. Unionised firms were also more likely to have adopted formal dispute resolution procedures, indicating that the near progressive rise in union density from the second half of the 1940s was also a significant influence on the rising incidence of conventional conflict resolution practices in firms. The formalisation of union recognition and collective bargaining arrangements in the public service over the same period also helps acccount for the near universality of conflict resolution procedures in public service organisations. There are few differences between unionised and non-union firms in general with respect to the adoption of ADR practices for managing conflict involving individual employees. While some non-union firms have adopted ADR practices for resolving individual conflict as part of wider strategies of 'union substitution' (Intel provides an example), it appears that non-union firms in general have not, to avoid recognising unions. Non-union firms were also found to have adopted a wider range of ADR practices for resolving group conflict, although unionised firms were more likely to have coupled these practices with conventional dispute resolution practices.

Union density has declined precipitously from the high water mark of the early 1980s, reaching a level of about 27 per cent in 2015. Unions on the whole have remained pragmatic in the face of employer initiatives in introducing various individual ADR practices, such as mediation. While expressing some concerns over the propensity of such initatives to loosen the level of influence they were able to exert over more conventional grievance procedures, union officials in general have recognised the advantages to members that may inhere in the provision of ADR options within grievance procedures, where more conventional rights or adjudication options remain available to union members (Teague et al., 2015, ch. 4). The unions involved have been more unambiguously supportive of collective ADR innovations like assisted bargaining, variants of med-arb or internal dispute panels. They have more often been parties to the genesis of these innovations, and recognise the advantages they can bring in terms of underpinning collective bargaining arrangements within organisations and even extending their influence over decision-making and bargaining outcomes in organisations (Teague et al., 2015, ch. 11-12). 
Second, the changing pattern of workplace conflict also influenced the development of conflict resolution in workplaces. The volume of strike activity rose significantly during the 1960s and 1970s (see Teague et al., 2015, p. 23) - decades during which conventional dispute resolution procedures became almost standard in mediumsized and large firms. Relatedly, successive national pay agreements from 1970 to 1980 made provision for disputes to be resolved within domestic dispute resolution procedures, before unresolved disputes were referred to the LRC and the Labour Court (O'Brien, 1981, ch. 12). This feature of national pay agreements is also likely to have encouraged the further adoption or formalisation of conventional dispute resolution procedures. While collective workplace conflict has since declined significantly, remaining disputes and work stoppages have serious implications for firms - possibly more serious than in the past, due to increasingly competitive commercial conditions, greater international competition in markets and, in the case of multinational subsidiaries, intense competition for investment by Irish subsidiary plants within parent companies. The vulnerability of firms to collective disputes, especially when faced with major restructuring programmes, is an important reason for the adoption of ADR practices like facilitation. Also significant in the emergence of facilitation has been the growing complexity of collective bargaining negotiations more generally, as employers and unions now more commonly and often repeatedly face complex restructuring and change programmes, sometimes allied to attempts to rebuild employment relations. These changes in the environment and scope of collective bargaining help explain both the incidence of different forms of collective ADR and systemic approaches to the adoption of collective ADR, such as the hybrid ADR system, discussed in the paper.

A pronounced long-term rise in the incidence of individual employment grievances handled by state agencies such as the Rights Commissioners, the EAT and the Equality Tribunal contributes to explaining the growing incidence of different forms of individual ADR. This development in part reflects the dramatic expansion that has occurred in the volume of employment legislation extending individual employment rights, particularly from the 1990s (see Teague at al., 2015, ch. 2). The genesis of workplace mediation can be traced to a series of codes of practice covering bullying and harrassment at work, promulgated by state agencies such as the Health and Safety Authority, the Equality Authority and the LRC during the first decade of the 2000s. 
Third, the growing presence of multinational firms in Ireland has also contributed to the rising incidence of ADR practices. Multinational subsidiaries are more likely to have adopted a range of individual forms of ADR, such as 'hotline' and 'speak-up' services and organisational ombudsmen. In the specific case of non-union multinational subsidiaries, managers' apparent concern not to be associated with innovation surrounding conflict management has constrained the systematic adoption of ADR practices. Multinational subsidiaries are also more likely to have adopted ADR practices for resolving conflict involving groups of employees, although Irish-owned firms are more likely to couple such practices with conventional dispute resolution practices - probably reflecting a combination of their dispute resolution legacies and the need to add ADR practices when faced with the challenges handling disjunctive commercial change, such as deregulation or privatisation.

Finally, if different forms of ADR have grown in part due to demand-side influences, such as changes in the features or commercial environments of workplaces, rising individual conflict at work and a growth in employment rights, the significance of supply-side influences should also be recognised. There has been very significant growth in the numbers of people undergoing training and education in mediation and other forms of conflict resolution and in those offering expert services in the field. The number of members of the Mediators' Institute of Ireland claiming expertise and interest in organisational and workplace mediation stands at over five hunded (see Teague et al., 2015, p. 95), although the number of regular mediation practitioners is likely to be significantly fewer than this. A range of private providers of facilitation services have also emerged, whether working in firms or as sole practitioners. This increased supply of trained professionals is an important influence in contributing to the institutionalisation of ADR in workplaces.

\section{Conclusions and likely future developments}

By the 1990s grievance and disputes procedures had become near standard features of medium and large workplaces in Ireland, reflecting both the professionalisation of personnel/human resource mangement, growing union density from the second half of the 1940s and the rising volume of workplace conflict from the 1960s. The headline development from the 1990s has been the growing uptake by firms of so-called ADR practices that both depart from and extend 
more long-standing conventional procedures for resolving workplace conflict. This development has been linked to a series of demand-side and supply-side influences.

What does the future hold? It seems likely that the incidence of ADR practices will continue to rise as employers, employees and unions seek new and more effective means of resolving workplace conflict - in particular, options based on 'interest-based' practices, like mediation, collective facilitation or med-arb, that prioritise compromises and solutions with which the parties can live, and that avoid or postpone adjudication or 'rights-based' solutions. In those instances where adjudication may be unavoidable, there is likely to be a rise in the incidence of in-house forms of adjudication like arbitration, disputes tribunals and review panels of different types. With growing demand for ADR options there is likely to be a continuing growth in the supply of trained professionals. Other professionals, such as lawyers, hitherto wedded to litigation and adjudication, are likely to show increasing interest in ADR as an extension of services available to clients.

It remains a more open question whether there will be a significant growth in the incidence of CMSs, based on integrated sets of interestbased and rights-based conflict resolution practices. Though the case for integrated CMSs has been pressed in the prescriptive literature, especially in contributions of North American provenance, the evidence to date for Ireland is that few organisations have adopted the strategic approach to conflict resolution seen as an essential underlying feature of the adoption of CMSs. Those who have acted strategically have not opted to introduce CMSs on the US model (Teague et al., 2015).

Most organisations continue to improvise ADR-based innovations in response to specific challenges and problems, eschewing a strategic approach to conflict resolution. Some, however, have been described as 'consolidators', meaning that they have extended and enhanced innovations where they were seen as effective and aligned them with overall HR and employment relations strategies (Roche et al., 2016). Consolidation might in this sense be a stepping stone along the road to the adoption of CMSs. Whether many organisations will travel this road, however, may be strongly influenced by the external environment. The widespread adoption of CMSs by large corporations in the US in considerable degree reflects an external institutional environment in which employment litigation is both widespread and very costly, and where the ready access to free state-provided conflict 
resolution services may in practice be unavailable (see Lipsky et al., 2016). The institutional environment in Ireland remains very different and favours the more limited and conservative adoption of ADR innovations.

\section{References}

Commission of Inquiry on Industrial Relations. (1981). Report of the Commission of Inquiry on Industrial Relations. Dublin: The Stationery Office.

Doherty, L., \& Teague, P. (2012). Conflict management systems in subsidiaries of non-union multinational organisations located in the Republic of Ireland. International Journal of Human Resource Management, 22 (1), 57-71.

Federated Union of Employers. (1980). Guide to industrial relations. Dublin: Federated Union of Employers.

Geary, J., \& Roche, W. K. (2000). Collaborative production and the Irish boom: Work organisation, partnership and direct involvement in Irish workplaces. Economic and Social Review, 31 (1), 1-36.

Gorman, L., Hynes, G., McConnell, J., \& Moynihan, T. (1975). Irish industry: How it's managed. Dublin: Irish Management Institute.

Gunnigle, P., \& Brady, T. (1984). The management of industrial relations in the small firm. Employee Relations, 6 (5), 21-4.

Hann, D., Roche, W. K., \& Teague, P. (2009). Managing workplace conflict in Ireland. Dublin: The Stationery Office.

Health Service Executive. (2009a). Mediation memo from National Director of Human Resources. Retrieved from https://pnd.hseland.ie/download/pdf/ mediation_memo.pdf [11 November 2016].

Health Service Executive. (2009b). 2009 Annual report: Mediation service. Retrieved from https://pnd.hseland.ie/download/pdf/2009_annual_ mediation_report_2nd_february_2010.pdf [11 November 2016].

Lipsky, D., Avgar, A., \& Lamare, J. R. (2016). The evolution of conflict management policies in US coporations: From reactive to proactive. In R. Saundry, P. Latreille, \& I. Ashman (Eds), Reframing resolution: Innovation and change in the management of workplace conflict. London: Palgrave Macmillan.

Murray, S. (1984). Survey of employee industrial relations in Irish private sector manufacturing industries. Dublin: Industrial Development Authority.

O'Brien, J. (1981). A study of national wage agreements in Ireland. Dublin: Economic and Social Research Institute.

O'Connell, P. J., Calvert, E., \& Watson, D. (2007). Bullying in the workplace: Survey reports, 2007. Dublin: Department of Enterprise, Trade and Employment.

Roche, W. K. (1992). The liberal theory of industrialism and the development of industrial relations in Ireland. In J. H. Goldthorpe \& C. T. Whelan 
(Eds), The development of industrial society in Ireland. London: The British Academy.

Roche, W., \& Teague, P. (2011). Firms and innovative conflict management systems in Ireland. British Journal of Industrial Relations, 49 (3), 436-59.

Roche, W. K., \& Teague, P. (2012a). Do conflict management systems matter? Human resource management, 51 (2), 231-58.

Roche, W., \& Teague, P. (2012b). Human resource management and ADR practices in Ireland. International Journal of Human Resource Management, 23 (3), 528-49.

Roche, W. K., Teague, P., Coughlan, A., \& Fahy, M. (2013). Recession at work: HRM in the Irish crisis. London: Routledge.

Roche, W. K., Teague, P., Gormley, T., \& Currie, D. (2016). Improvisers, consolidators and strategists: How organisations adopt ADR innovations. Unpublished manuscript, College of Business, University College Dublin, \& Management School, Queen's University Belfast.

Teague, P., \& Doherty, L. (2011). Conflict management systems in subsidiaries of non-union multinational organisations located in the Republic of Ireland. Dublin: Labour Relations Commission.

Teague, P., \& Roche, W. K. (2012). Line managers and the management of workplace conflict. Human Resource Management Journal, 22 (3), 235-51.

Teague, P., Roche, W. K., Gormley, T., \& Currie, D. (2015). Managing workplace conflict: Alternative dispute resolution in Ireland. Dublin: Institute of Public Administration.

Von Prondzynski, F., \& Richards, W. (1994). European employment and industrial relations glossary: Ireland. Dublin: European Foundation for the Improvement of Living and Working Conditions.

Wallace, J. (1987). Procedure agreements and their place in workplace industrial relations. In A. Kelly, T. Murphy \& B. Hillery (Eds), Industrial relations in Ireland: Contemporary issues and developments. Dublin: Department of Industrial Relations, University College Dublin.

Watson, D., Galway, J., O'Connell, P., \& Russell, H. (2009). The changing workplace: A survey of employers' views and experiences. Dublin: National Centre for Partnership and Performance.

Williams, J., Blackwell, S., Gorby, S., O'Connell, P. \& Russell, H. (2003). The changing workplace: A survey of employers' views and experiences. Dublin: National Centre for Partnership and Performance. 